Article

\title{
Microbiological Changes in Meat and Minced Meat from Beavers (Castor fiber L.) during Refrigerated and Frozen Storage
}

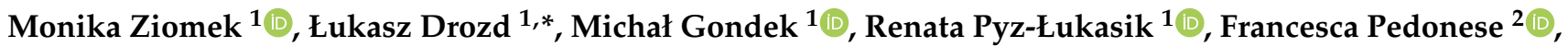 \\ Mariusz Florek $^{3}$ (D), Piotr Domaradzki ${ }^{3}$ (D) and Piotr Skałecki ${ }^{3}$
}

check for updates

Citation: Ziomek, M.; Drozd, Ł.; Gondek, M.; Pyz-Łukasik, R.; Pedonese, F.; Florek, M.; Domaradzki, P.; Skałecki, P. Microbiological Changes in Meat and Minced Meat from Beavers (Castor fiber L.) during Refrigerated and Frozen Storage. Foods 2021, 10, 1270. https:// doi.org/10.3390/foods10061270

Academic Editor: Maria João dos Ramos Fraqueza

Received: 31 March 2021

Accepted: 31 May 2021

Published: 2 June 2021

Publisher's Note: MDPI stays neutral with regard to jurisdictional claims in published maps and institutional affiliations.

Copyright: (c) 2021 by the authors. Licensee MDPI, Basel, Switzerland. This article is an open access article distributed under the terms and conditions of the Creative Commons Attribution (CC BY) license (https:/ / creativecommons.org/licenses/by/ $4.0 /)$.
1 Department of Food Hygiene of Animal Origin, University of Life Sciences in Lublin, Akademicka 12, 20-950 Lublin, Poland; monika.ziomek@up.lublin.pl (M.Z.); michal.gondek@up.lublin.pl (M.G.); renata.pyz@up.lublin.pl (R.P.-Ł.)

2 Department of Veterinary Sciences, University of Pisa, Viale delle Piagge 2, 56124 Pisa, Italy; francesca.pedonese@unipi.it

3 Faculty of Animal Sciences and Bioeconomy, Institute of Quality Assessment and Processing of Animal Products, University of Life Sciences in Lublin, Akademicka 13, 20-950 Lublin, Poland; mariusz.florek@up.lublin.pl (M.F.); piotr.domaradzki@up.lublin.pl (P.D.); piotr.skalecki@up.lublin.pl (P.S.)

* Correspondence: lukasz.drozd@up.lublin.pl; Tel.: +48-81-445-62-56

\begin{abstract}
This study aims to evaluate the microbiological status, $\mathrm{pH}$, and water activity of European beaver meat to establish its shelf-life and microbiological safety. In this study, the microbiological profiles of meat and minced meat obtained from the carcasses of beavers were investigated. Microbial evaluation of the chilled meat was performed within $24 \mathrm{~h}$ after hunting, on the 7th day and 14th day, and the evaluation of the frozen meat was made during the 11th week of storage. Meat samples were analysed for total viable count (TVC), psychrotrophic bacteria count (PBC), Enterobacteriaceae count (EBC), Escherichia coli count (EC), total staphylococcal count (TSC), lactic acid bacteria count (LABC) and total yeast and mould counts (TYMC). Tests for the presence of pathogenic bacteria from the genus Salmonella and Listeria were also performed. Additionally, the $\mathrm{pH}$ and water activity were determined. The initial amount of TVC was $4.94 \mathrm{log}$ CFU/g in meat samples and $4.80 \mathrm{log}$ CFU/g in minced meat. After 14 days of storage, the TVC increased to 8.33 in meat samples and $8.08 \log$ CFU/g in minced meat. Pathogenic bacteria such as Listeria and Salmonella were not found in the beaver meat tested. The microbiological state of meat stored frozen for 11 weeks was comparable to the state found in meat stored refrigerated for seven days regarding the number of microorganisms.
\end{abstract}

Keywords: minced meat; game meat; microbiological profile; Castor fiber L.

\section{Introduction}

The beaver (Castor fiber L.) is the largest living rodent in Europe and the second largest in the world after the capybara. It is an aquatic and terrestrial animal, has a nocturnal lifestyle and shows strong territoriality. In Poland, according to the regulation of the Polish Ministry on Environment from December 2016, the beaver population is under partial species protection [1]. The inclusion of beavers on the list of endangered species and the "Active Beaver Protection Programme" led by the Research Station of the Polish Academy of Science in Popielno and the Polish Hunting Association led to significant growth in the beaver population in Poland. Over the years, from 2000 to 2018, a 4-fold increase in the population's size was observed. According to data from Statistics Poland [2], in 2018, the population of beavers in Poland consisted of about 125,000 individuals. For this reason, the Minister for the Environment agreed to a partial reduction. This reduction is by culling, which is permitted through shooting with hunting weapons or trapping in a strictly defined season from 1 October to 15 March. The number of beaver individuals to be shot in Baltic Sea region countries is increasing from year to year [3]. As a result, beaver meat may become more available on the food market. Beaver meat is classified as game and is not a 
popular food species. However, this meat has well-appreciated culinary properties and was once considered a delicacy, especially the beaver's hind legs, liver and tail fin, to which aphrodisiac properties were attributed. Beaver meat can become a constituent of processed meat products, i.e., sausages, burgers, patties or meatballs made of different types of meat. Therefore, it seems appropriate to define its quality. In general, the meat quality concept includes eating pleasure, good appearance, physical properties, quality, nutritional value and safety. The physicochemical properties and nutritional value of beaver meat have already been described [4-7]. Beaver meat contains $21.50 \pm 1.01 \%$ of protein. The average percentage of indispensable amino acids reaches $45.00 \%$, and at the highest content in mussels are lysine $(1.85 \mathrm{~g} / 100 \mathrm{~g})$ and leucine $(1.65 / 100 \mathrm{~g})$ and within nonessential amino acids glutamine acid $(3.49 \mathrm{~g} / 100 \mathrm{~g})$ and aspartic acid $(1.89 \mathrm{~g} / 100 \mathrm{~g})$. The percentage of intramuscular fat from skeletal muscle is $1.99 \pm 1.13 \%$. The predominant class of fatty acids is polyunsaturated fatty acids (averaging $49.39 \%$ ), followed by saturated fatty acids $(27.81 \%)$ and monounsaturated cis fatty acids (15.96\%). Linoleic acid (LA, 18:2 n-6) is the most abundant fatty acid in intramuscular fat ( $>34 \%$ of total). The $\mathrm{pH}$ value of beaver meat changes during cold storage and ranged from 5.61 after $24 \mathrm{~h}$ to 6.10 after 7 days [8,9]. Therefore, there would seem to be merit in undertaking research assessing the safety of this meat and its resistance to deterioration when stored in refrigerated conditions. There is little information available in the literature on biological hazards related to the consumption of beaver meat. The most widely described disease borne by it is Tularemia caused by Francisella tularensis. Tularemia may be derived from inadequately cooked beaver meat [10]. Beavers are also indicated as a source of the Echinococcus multilocularis and Echinococcus granulosus tapeworms, and Trichinella spp. roundworms [11-15]. The microbiological quality of game varies greatly and depends on many factors, e.g., the microflora on the surface and in the digestive tract of animals; the hunting methods; the location of the projectile injury; the place where the game was hunted; the time needed, a technique used, and hygienic conditions provided during gutting; the temperature, duration and hygiene during transport to the cooling point; and technical and sanitary conditions during skinning, butchering of hunted prey carcasses [16-19]. The risk of microbiological contamination of game meat after hunting is reduced if the animal is quickly found and eviscerated [16]. Studies show that immediately after hunting, the number of microbes in the meat is negligible. It should, therefore, be assumed that the microbiological status of wild meat will vary widely.

It should also be stressed that other factors, such as the chemical composition of meat, gaseous environment and nutrient availability, as well competition from other bacteria, also affect how any particular bacteria may grow in this matrix [20].

Minced meat is produced from fresh or frozen skeletal muscles together with the fatty tissue attached to them. In the mincing process, the cellular structure of the muscle tissue is irretrievably lost, and as a result, minced meat becomes a highly nutritious and perishable product. Due to redistribution of surface contamination throughout the whole mass, such a product is in jeopardy of rapid bacterial growth. For the meat industry, the question of how long the maximum storage time of raw meat can be from slaughter until mincing is still unresolved [21].

Taking into account the growing population of beavers in Poland and the possibility of hunting these animals, it is expedient to determine the microbiological status of beaver meat in the context of microbiological criteria established by food law and commonly used parameters for microbiological quality assessment of game. Therefore, the objective of the pilot study is to evaluate common food-borne and food spoilage bacteria prevalence in beaver meat and its shelf-life, as indicated by the change in microbiological contamination, water activity and $\mathrm{pH}$ value during storage. 


\section{Materials and Methods}

\subsection{Sampling}

The research material was prepared from male European beavers $(n=6)$. The animals were shot under reduction hunting by authorised hunters as members of the Polish Hunting Association from 5 to 14 March 2017 in controlled hunting zones inside Lublin voivodeship under two individual grants of permission (WPN.6401.33.2016.KM of 7 Apr 2016 and WPN.6401.85.2016.KM of 4 July 2016) and a regulation made by the Regional Director for Environmental Protection in Lublin on 30 November 2016 (the Official Journal of Lublin voivodeship of 1 Dec 2016, item 4828). After hunting, beavers were bled, eviscerated, skinned and weighed. An appropriately trained person examined the body and viscera of animals according to Chapter III of Section IV of Annex III to Regulation [22]. During the examination, no visible anomalies or signs suggestive of the meat posing a health risk were noticed. Eviscerated carcasses were transported to the laboratory in insulated containers within $24 \mathrm{~h}$ of shooting in compliance with the highest hygienic standards and keeping temperature throughout the meat below $4{ }^{\circ} \mathrm{C}$. The head, paws and tail fin were removed from each animal. For the purposes of this study, the left and right thighs were detached from each carcass, then deboned and trimmed of visible adipose and connective tissue. The principal muscles were collected from individual hind legs: the semimembranosus, semitendinosus, biceps femoris, gluteus medius, and quadriceps femoris. The muscles from the left thigh of each beaver were divided randomly into four separate samples and wrapped individually using sterile re-sealable polyethene bags (Fisherbrand ${ }^{\mathrm{TM}}, 540 \mathrm{~mL}$ ). The muscles from the right thighs were minced in sanitary conditions using a Predom-Mesko device (Poland) and divided into four individual samples. The samples thus prepared were stored refrigerated at $4{ }^{\circ} \mathrm{C}$ or frozen at $\left(-18^{\circ} \mathrm{C}\right)$ until they were analysed. Physicochemical measurements and microbial evaluation of refrigerated whole-muscle tissue and minced muscle tissue were performed initially within $24 \mathrm{~h}$ after hunting and subsequently on the 7th and 14th days. For frozen tissue, the evaluation was performed at the end of the 11th week of storage $\left(-18^{\circ} \mathrm{C}\right)$. Before analysis, frozen meat samples were thawed for $24 \mathrm{~h}$ at a temperature of $4{ }^{\circ} \mathrm{C}$. In total, 48 beaver meat samples were tested, 24 each of muscles and minced meat $(n=48)$.

\subsection{Microbiological Analysis}

For all microbiological counts, $10 \mathrm{~g}$ samples from each re-sealable bag were aseptically weighed into sterile lab bags (BagFilter $400 \mathrm{~mL}$, Interscience, Saint Nom la Brétèche, France) with $90 \mathrm{~mL}$ of dilution fluid-saline peptone water (BioMaxima, Lublin, Poland) and then were homogenised in a stomacher (Seward, Worthing, UK) for $2 \mathrm{~min}$ at the normal speed of $230 \mathrm{rpm}$ and as required by the PN-EN ISO 6887-3:2005 and PN-EN ISO 7218:2008 standards [23,24]. Other decimal dilutions were prepared from the $10^{-1}$ dilution and were plated onto appropriate media. The samples to provide TVC and PBC were cultivated on Plate Count Agar (BioMaxima, Poland) and enumerated after incubation at $30{ }^{\circ} \mathrm{C}$ for $48 \mathrm{~h}$ and $0-4{ }^{\circ} \mathrm{C}$ for 14 days, respectively $[25,26]$. Bacteria to be the source of EBC data were enumerated in Violet Red Bile with Lactose Agar (BioMaxima, Poland) after incubation at $37^{\circ} \mathrm{C}$ for $24 \mathrm{~h}$ [27]. The EC was determined using Tryptone Bile Xglucuronide Agar (BioMaxima, Poland) as the medium. Plates were incubated at $44^{\circ} \mathrm{C}$ for $24 \mathrm{~h}$ [28]. The LABC was facilitated by bacterial culture using de Man, Rogosa and Sharpe (MRS) agar (BioMaxima) as the medium. Plates were incubated at $30{ }^{\circ} \mathrm{C}$ for $48 \mathrm{~h}$ [29]. The TSC was estimated after culture using Baird-Parker agar and Brain Heart Infusion (Biomaxima, Poland) broth $\left(37^{\circ} \mathrm{C}\right.$ for $24 \mathrm{~h}$ in both cases) [30]. For the confirmation of coagulase-positive staphylococci, Rabbit Coagulase Plasma (Pro-Lab Diagnostics, Wirral, UK) and the SENSILAtest STAPHY 24 identification kit (Erba Lachema, Brno, Czech Republic) were used. The TYMC was ascertained through culture on an agar medium with Dichlorate Rose Bengal and Chloramphenicol LAB-AGAR (BioMaxima, Poland) [31]. The culture was incubated at $25{ }^{\circ} \mathrm{C}$ for five days. Isolation and determination of Salmonella spp. were performed according to PN-ISO 6579:2003 [32]. Twenty-five grams of a sample 
in $225 \mathrm{~mL}$ of buffered peptone water was homogenised in the stomacher and incubated at $37^{\circ} \mathrm{C}$ for $18 \mathrm{~h}$. After that, Rappaport-Vassiliadis broth (incubated at $41.5^{\circ} \mathrm{C}$ for $24 \mathrm{~h}$ ) and then xylose lysine deoxycholate (XLD) and brilliant green agar (BGA) (incubated at $37^{\circ} \mathrm{C}$ for $24 \mathrm{~h}$ ) were used. If no typical colonies appeared on XLD and BGA media, the test was discontinued according to the stipulations for the procedure in the ISO standard. In order to determine the presence of Listeria spp., an examination was performed guided by PN-EN ISO 11290-1 [33]. Twenty-five grams of a sample in $225 \mathrm{~mL}$ of half Fraser broth was homogenised in the stomacher and incubated at $30^{\circ} \mathrm{C}$ for $24 \mathrm{~h}$. Then, the homogenate was added to the Fraser broth, and the solution was incubated at $37^{\circ} \mathrm{C}$ for $24 \mathrm{~h}$. Subsequently, incubation took place again in Ottaviani and Agosti medium (ALOA) and Oxford medium at $37^{\circ} \mathrm{C}$ for $24-48 \mathrm{~h}$. Confirmatory tests were performed (Gram staining, mobility capacity, sugar fermentation, and hemolysis tests). Analyses were carried out on the materials from each re-sealable bag separately. All bacterial populations were determined as the log of colony-forming units $\left(\log \mathrm{CFU} \mathrm{g} \mathrm{g}^{-1}\right)$.

\section{3. $\mathrm{pH}$ Measurement}

The $\mathrm{pH}$ was measured in triplicate using a CP-401 portable $\mathrm{pH}$-meter (Elmetron, Poland) and an ERH-12-6 penetrating glass electrode (Hydromet, Poland) calibrated at the 2 points $\mathrm{pH} 4.00$ and $\mathrm{pH} 7.00$ with high-accuracy $\mathrm{pH}$ buffer solutions $\left( \pm 0.02\right.$ at $20^{\circ} \mathrm{C}$; Elmetron, Poland). The $\mathrm{pH}$ meter allowed for the automatic detection of buffer solutions and automatic temperature compensation.

\subsection{Water Activity Measurement}

The water activity was measured in triplicate using a HygroLab C1 water activity meter (Rotronic, Bassersdorf, Switzerland). Measurements were made using the AWQ mode and allowing stabilisation for $15 \mathrm{~min}$ after samples had reached room temperature.

\subsection{Statistical Analysis}

A statistical analysis of the data was performed using Statistica 13 (Tibco, Palo Alto, CA, USA). Statistical differences were determined by one-way analysis of variance (ANOVA) and Tukey's post-hoc test. A $p$-value of $\leq 0.05$ was considered statistically significant for all comparisons. All data are presented as means $\pm \mathrm{SD}$.

\section{Results}

\subsection{Bacterial Contamination of Carcasses}

In the studies carried out, a statistically significant increase in the number of microbes was found from earlier to later days of cold storage in all the bacteria studied: TVC, PBC, EBC, EC, LABC, TSC, and TYMC (Table 1). The TVC in the meat samples tested showed an upward trend from 4.94 to $8.33 \log C F U / g$. In parallel with the lengthening time of storage of meat, the PBC increased from 3.98 to $8.46 \log \mathrm{CFU} / \mathrm{g}$. The EBC rose from 3.27 to $5.70 \log \mathrm{CFU} / \mathrm{g}$ and the EC from 3.11 to $4.80 \mathrm{log}$ CFU/g. LABC were detected in the meat samples in the number of 3.68 to $6.01 \mathrm{log}$ CFU/g. The TSC increased from 3.03 to $4.46 \mathrm{log}$ CFU/g and TYMC from 3.11 to $4.80 \log$ CFU/g. There was a statistically significant rise in the number of bacteria except for TVC in the samples of frozen meat in all bacterial counts taken, and the $\mathrm{PBC}$ was comparable to that determined on the seventh day of cold storage.

In Table 2, the numbers of microorganisms (TVC, PCB, EBC, EC, LABC, TSC, and TYMC) are shown, which were detected in minced beaver meat on $24 \mathrm{~h}, 7$ and 14 days of refrigerated storage and in frozen minced meat after 11 weeks of storage. The growth of microorganisms in the minced meat during storage showed similar trends to those in the stored samples, which had not been minced. The TVC in refrigerated minced meat rose from 4.80 to $8.08 \mathrm{log}$ CFU/g. The PBC also showed proliferation from 3.62 to $8.33 \log$ CFU/g. Significant increases were also observed in other microbe counts. The EBC increased from 3.34 to $5.70 \log \mathrm{CFU} / \mathrm{g}$ and the EC from 1.34 to $1.70 \log \mathrm{CFU} / \mathrm{g}$. The growth in $\mathrm{LABC}$ was from 3.4 to $5.66 \log \mathrm{CFU} / \mathrm{g}$, that of the TSC from 3.00 to $4.27 \mathrm{CFU} / \mathrm{g}$ and the 
rise in the TYMC was from 3.22 to $4.80 \mathrm{CFU} / \mathrm{g}$. In frozen minced meat, bacterial growth in all groups apart from PBC was comparable to that observed on Day 7 of refrigeration. The studies carried out did not reveal statistically significant differences in the number of relevant microorganisms on individual storage days between minced meat and meat with preserved tissue structure.

Table 1. Microbiological counts (log CFU/g and \% TCV) of a different microbial group of beaver meat samples $(n=6)^{a}$.

\begin{tabular}{ccccc}
\hline \multirow{2}{*}{ Microorganism $^{b}$} & \multicolumn{3}{c}{ Time of Storage } & Weeks of Frozen \\
\cline { 2 - 5 } & $\mathbf{2 4} \mathbf{~ h}$ & 7 Days & $\mathbf{1 4}$ Days & $\mathbf{1 1}$ \\
\hline TVC & $4.94 \pm 0.17 \mathrm{~A}$ & $7.07 \pm 0.45 \mathrm{~B}$ & $8.33 \pm 0.25 \mathrm{C}$ & $5.97 \pm 0.27 \mathrm{D}$ \\
PBC & $3.98 \pm 0.44 \mathrm{~A}$ & $5.54 \pm 0.31 \mathrm{~B}$ & $8.46 \pm 0.24 \mathrm{C}$ & $4.71 \pm 0.28 \mathrm{D}$ \\
EBC & $3.27 \pm 0.29 \mathrm{~A}$ & $4.91 \pm 0.13 \mathrm{~B}$ & $5.70 \pm 0.19 \mathrm{C}$ & $3.82 \pm 0.38 \mathrm{~B}$ \\
EC & $1.37 \pm 0.27 \mathrm{~A}$ & $1.54 \pm 0.18 \mathrm{AB}$ & $1.72 \pm 0.15 \mathrm{~B}$ & $1.52 \pm 0.25 \mathrm{AB}$ \\
LABC & $3.68 \pm 0.37 \mathrm{~A}$ & $5.17 \pm 0.47 \mathrm{~B}$ & $6.01 \pm 0.52 \mathrm{C}$ & $4.51 \pm 0.19 \mathrm{~B}$ \\
TSC & $3.03 \pm 0.13 \mathrm{~A}$ & $3.74 \pm 0.16 \mathrm{~B}$ & $4.46 \pm 0.32 \mathrm{C}$ & $3.68 \pm 0.12 \mathrm{~B}$ \\
TYMC & $3.11 \pm 0.29 \mathrm{~A}$ & $4.29 \pm 0.53 \mathrm{~B}$ & $4.80 \pm 0.15 \mathrm{C}$ & $3.77 \pm 0.12 \mathrm{~B}$ \\
\hline
\end{tabular}

${ }^{a}$ Within rows, means with different letters are significantly different $(p<0.05) .{ }^{b}$ TVC, Total Viable Count; PBC, Psychrotrophic Bacteria Count; EBC, Enterobacteriaceae Count; EC, E. coli count; TSC, Total Staphylococcal Count; LABC, Lactic Acid Bacteria count; TYMC, Total Yeast and Mould Counts.

Table 2. Microbiological counts (log CFU/g) of a different microbial group for minced meat of beaver $(n=6)^{a}$.

\begin{tabular}{ccccc}
\hline \multirow{2}{*}{ Microorganism $^{b}$} & \multicolumn{3}{c}{ Time of Storage } & Weeks of Frozen \\
\cline { 2 - 5 } & $\mathbf{2 4} \mathbf{~ h}$ & 7 Days & 14 Days & $\mathbf{1 1}$ \\
\hline TVC & $4.80 \pm 0.42 \mathrm{~A}$ & $6.44 \pm 0.65 \mathrm{~B}$ & $8.08 \pm 0.68 \mathrm{C}$ & $5.78 \pm 0.17 \mathrm{~B}$ \\
PBC & $3.62 \pm 0.36 \mathrm{~A}$ & $5.94 \pm 0.61 \mathrm{~B}$ & $8.33 \pm 0.19 \mathrm{C}$ & $4.30 \pm 0.39 \mathrm{D}$ \\
EBC & $3.34 \pm 0.30 \mathrm{~A}$ & $4.03 \pm 0.37 \mathrm{~B}$ & $5.70 \pm 0.24 \mathrm{C}$ & $3.98 \pm 0.32 \mathrm{~B}$ \\
EC & $1.34 \pm 0.26 \mathrm{~A}$ & $1.52 \pm 0.18 \mathrm{AB}$ & $1.70 \pm 0.13 \mathrm{~B}$ & $1.51 \pm 0.23 \mathrm{AB}$ \\
LABC & $3.47 \pm 0.49 \mathrm{~A}$ & $4.69 \pm 0.47 \mathrm{~B}$ & $5.66 \pm 0.14 \mathrm{C}$ & $4.18 \pm 0.49 \mathrm{~B}$ \\
TSC & $3.00 \pm 0.25 \mathrm{~A}$ & $3.70 \pm 0.33 \mathrm{~B}$ & $4.27 \pm 0.50 \mathrm{C}$ & $3.74 \pm 0.15 \mathrm{BC}$ \\
TYMC & $3.22 \pm 0.19 \mathrm{~A}$ & $4.02 \pm 0.34 \mathrm{~B}$ & $4.80 \pm 0.09 \mathrm{C}$ & $3.70 \pm 0.16 \mathrm{~B}$ \\
\hline
\end{tabular}

${ }^{a}$ Within rows, means with different letters are significantly different $(p<0.05) .{ }^{b}$ TVC, Total Viable Count; PBC, Psychrotrophic Bacteria Count; EBC, Enterobacteriaceae Count; EC, E. coli count; TSC, Total Staphylococcal Count; LABC, Lactic Acid Bacteria count; TYMC, Total Yeast and Mould Counts.

\section{2. $\mathrm{pH}$ and Water Activity Changes}

A significant $(p<0.000)$ decrease in $\mathrm{pH}$ was observed during refrigerated storage up to Day 14 (to 5.69 for whole-muscle and 5.75 for minced tissue) (Figure 1). However, the highest $\mathrm{pH}$ values were determined after 11 weeks of frozen storage (5.82 for muscle tissue and 5.86 for minced meat). Nevertheless, the $\mathrm{pH}$ measurements obtained in the present research indicate the correct level of meat acidification from the technological and hygienic point of view.

Refrigerated storage duration up to Day 14 significantly $(p<0.000)$ decreased water activity $\left(\mathrm{a}_{\mathrm{W}}\right)$ in both groups of examined beaver meat, from 0.993 to 0.988 for whole-muscle tissue and from 0.992 to 0.988 for minced meat. In turn, the level of aw after frozen storage over 11 weeks (0.991) did not differ significantly from those on $24 \mathrm{~h}$ after shooting (0.993) and 7 (0.990) for refrigerated samples of muscle tissue and was similar to that on Day 7 (0.992) for minced meat (Figure 2). 


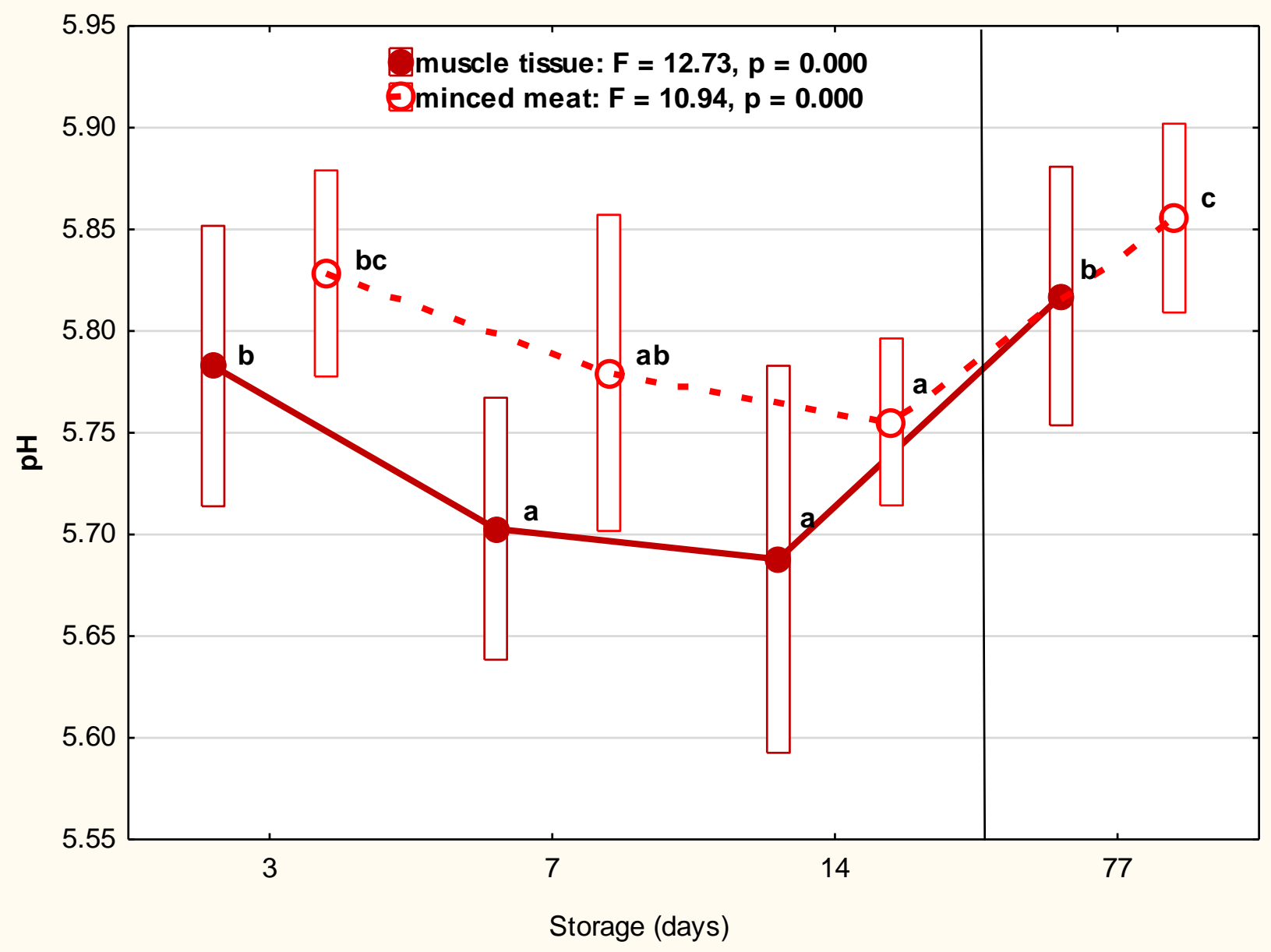

Figure 1. The $\mathrm{pH}$ of muscle tissue and minced meat of beaver during refrigerated $(1,7,14$ days) and frozen (77 days) storage. Red filled dots represent the average $\mathrm{pH}$ value of muscle tissue. The continuous line represents the trends in changes between storage days. The red empty dots represent the average $\mathrm{pH}$ value in minced meat. The dotted line represents the trends in changes between storage days. Bars represent the standard deviation. The mean values marked with letters ( $a$, $b$, c) differ statistically at $p \leq 0.05$. 


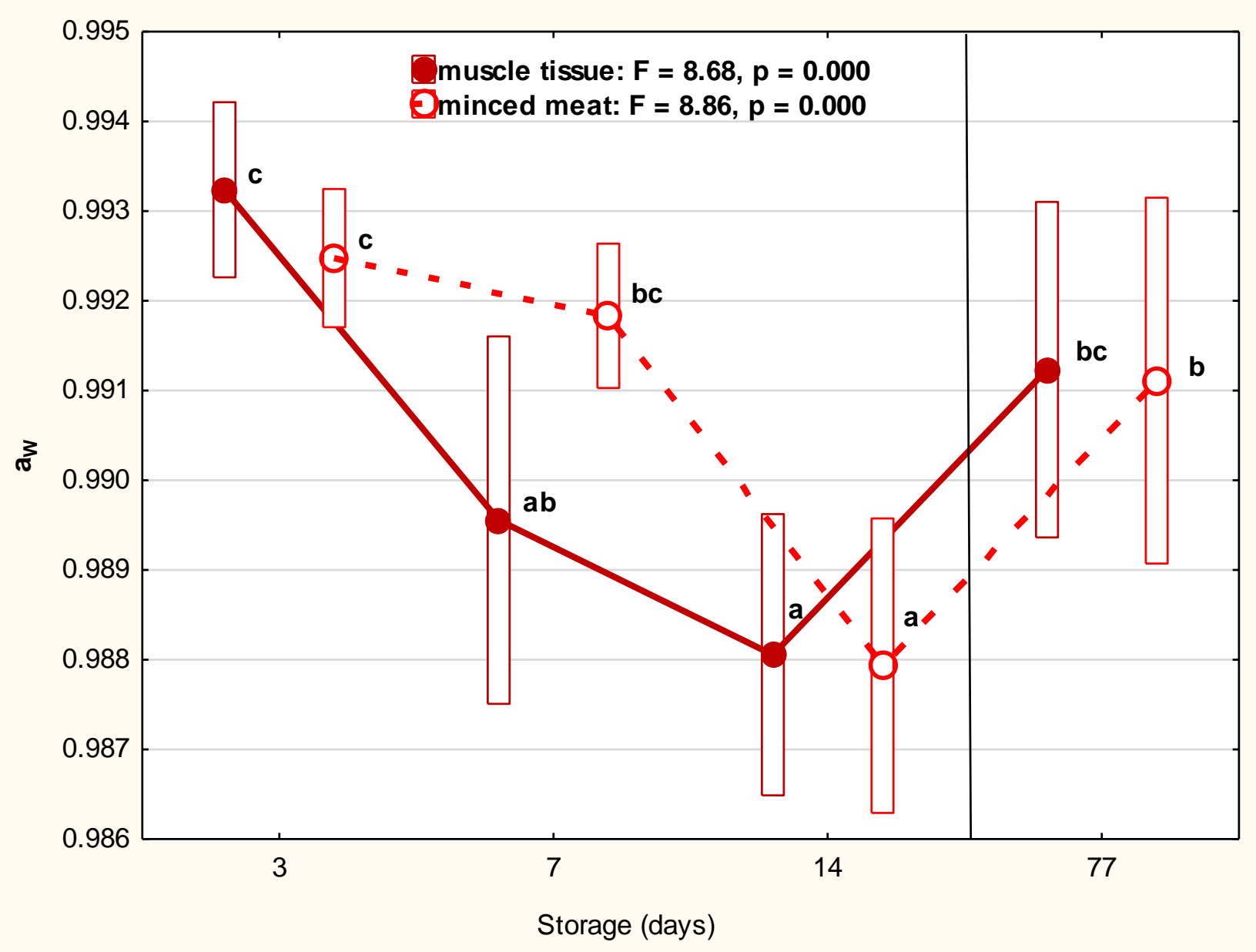

Figure 2. The water activity of muscle tissue and minced meat of beaver during storage. The $\mathrm{a}_{\mathrm{w}}$ of muscle tissue and minced meat of beaver during refrigerated (1, 7, 14 days) and frozen (77 days) storage. Red filled dots represent the average $\mathrm{a}_{\mathrm{w}}$ value of muscle tissue. The continuous line represents the trend in changes between storage days. The red empty dots represent the average $\mathrm{a}_{\mathrm{w}}$ value in minced meat. The dotted line represents the trend in changes between storage days. Bars represent the standard deviation. The mean values marked with letters $(\mathrm{a}, \mathrm{b}, \mathrm{c})$ differ statistically at $p \leq 0.05$.

\section{Discussion}

Many factors associated with post-mortem treatment of the carcasses determine the microbiological parameters of game meat and as a consequence play an important role in its initial hygienic status. The initial microbiological status of the meat has a significant impact on how safe it is and how long the storage period can be [16-18,34]. It is well known that the initial microbiological status of the meat determines the safety of meat for the consumers as well as length of its storage period. The TVC, EC and presence of Salmonella were evaluated to establish compliance with the European food law requirements [35]. Additionally, commonly used food hygiene criteria such as EBC, PBC, LABC, TYMC and presence of Listeria were also evaluated. The EBC is used for determining the level of microbiological contamination of carcasses and meat derived from them, while the total numbers of $\mathrm{PBC}$ and $\mathrm{LABC}$ determine the hygienic status of refrigerated meat. In contrast, the TYMC and presence of Listeria found in the carcasses and meat indicate that the source of these microorganisms should be linked with the environment in which post-slaughter dressing and dismemberment of carcasses were performed. 


\subsection{The Microbiological Parameters}

There are currently few data available on the contamination of beaver meat. The TVC in the meat of beavers obtained $24 \mathrm{~h}$ after their shooting in Lithuania was found to be $3.94 \log \mathrm{CFU} / \mathrm{g}$ [9]. In the studies performed for this investigation, the TVC and $\mathrm{PBC}$ in beaver meat on $24 \mathrm{~h}$ after shooting were comparable to those yielded in a muscle (M. longissimus dorsi) of male deer in north-eastern Poland, where the TVC was $5.10 \log$ $\mathrm{CFU} / \mathrm{g}$ and the $\mathrm{PBC} 3.80 \log \mathrm{CFU} / \mathrm{g}$, which may indicate a comparable level of overall microbiological contamination of game meat [36]. The TVC exhibited a rising trend during refrigerated storage. Similar relationships were found during the storage of meat obtained from the hind leg and shoulder of wild boars [37].

Enterobacteriaceae, including E. coli, are a typical indicator of faecal contamination, and their presence in muscle tissue may primarily indicate the presence of intestinal pathogens and accelerate the process of meat spoilage. In the case of game animals, the presence of Enterobacteriacea bacteria may also indicate that the animal was killed with poor shot placement, as well as indicate delayed gutting [38]. It has been confirmed that contamination with Enterobacteriaceae in the carcasses of wild animals shot unskilfully is significantly higher than contamination in carcasses of animals killed with good shot placement $[16,39]$. The average Enterobacteriaceae contamination found in the meat of beavers shot in Lithuania was $1.84 \pm 0.11 \log \mathrm{CFU} / \mathrm{g}$ at $24 \mathrm{~h}$ post kill [9]. In studies of wild boar meat shot in Poland, lower numbers of Enterobacteriaceae were found: $1.69 \log$ CFU/g after $48 \mathrm{~h}$ and $2.43 \log \mathrm{CFU} / \mathrm{g}$ after $360 \mathrm{~h}$ of storage at $2{ }^{\circ} \mathrm{C}$ [40]. Contamination with Enterobacteriaceae in wild animal meat is highly variable. This is confirmed by studies of fresh wild boar meat from southern Italy, where the level of Enterobacteriaceae in individual individuals ranged from 0.00 to $5.67 \mathrm{log}$ CFU/g [39]. During the storage of fresh meat of wild animals, microorganisms of the Enterobacteriaceae family may constitute an important part of the overall microbial contamination. The ratio of the number of Enterobacteriaceae to the total number of microorganisms in studies carried out in Latvia was constant across all storage periods of roe and red deer meat and accounted for $60 \%$ of the total number of bacteria [41].

Lactic acid bacteria are widespread in the natural environment as well as in the production environment, and their presence on carcasses and meat is unavoidable. Heterofermentative strains of Lactobacillus (Lactobacillus spp., mainly L. curvatus and L. sakei), heterofermentative Leuconostoc (Leuconostoc spp.) and Carnobacterium spp. are the principal microorganisms that cause meat spoilage. The multiplication of heterofermentative strains of LAB during meat storage causes organoleptic changes, i.e., in smell and colour, and leads to the formation of threads of slime (ropy slime formation) [42]. The reason for these changes is in the production of a significant number of undesirable catabolites, such as $\mathrm{CO}_{2}$, ethanol, acetic acid, butanoic acid, and acetoin. The available literature notes a level of contamination of beaver meat with LAB bacteria of $1.38 \log$ CFU/g $24 \mathrm{~h}$ after the shooting [9]. In wild boar meat, the amount of lactic acid bacteria in fresh samples ranged from 0.00 to $5.61 \log \mathrm{CFU} / \mathrm{g}$, which indicates a wide variation in the contamination of wild boar with lactic acid bacteria [39].

One of the causes of human food poisoning is the presence in food of staphylococcal enterotoxins produced by coagulase-positive $S$. aureus strains. The presence of coagulasepositive Staphylococcus aureus spp. aureus was confirmed in only one sample of minced meat. In the studies presented by Lawson et al., species analysis was performed on catalasenegative Staphylococcus strains isolated from European beavers, and it confirmed the new Staphylococcus species Streptococcus castoreus sp. nov. [43].

Game meat can also be a source of pathogenic Salmonella spp. and Listeria spp. bacteria. Studies of fresh wild boar meat from southern Italy have shown the presence of Salmonella bacilli in almost one-third of samples (31.82\%) [39]. The results of the studies presented by Atanassova show that game meat can be contaminated with Listeria spp. bacteria. Listeria was confirmed in $4.8 \%$ of the game meat samples examined [16]. The studies carried out did not reveal the presence of microorganisms of the Listeria or Salmonella genus. Similar 
results were obtained in studies of wild boar meat, which also did not detect the presence of these bacteria [40].

Current EU food law imposing microbiological criteria does not set down hygiene requirements for wild animal carcasses. However, the regulation does adopt as law a food safety criterion for minced meat and raw meat products produced from the meat of species other than poultry and intended for consumption after heat treatment. This criterion is the absence of Salmonella in $25 \mathrm{~g}$. According to this criterion, each test batch of minced meat should be considered satisfactory if no Salmonella bacilli are found in any of the five samples of $25 \mathrm{~g}$ (representing the batch). The hygienic criteria that signal the level of microbiological contamination of minced meat are TVC and EC. The established contamination limits defined by the limit $(\mathrm{m})$ and maximum $(\mathrm{M})$ number of microorganisms per gram of minced meat are as follows: $\mathrm{m}=5 \times 10^{5} \mathrm{CFU} / \mathrm{g}(5.7 \log \mathrm{CFU} / \mathrm{g}), \mathrm{M}=5 \times 10^{6} \mathrm{CFU} / \mathrm{g}$ ( $6.7 \log \mathrm{CFU} / \mathrm{g}$ ) for TVC; and $\mathrm{m}=50 \mathrm{CFU} / \mathrm{g}, \mathrm{M}=500 \mathrm{CFU} / \mathrm{g}$ for $E$. coli. The hygienic quality of the process is considered unsatisfactory if at least one of the five contamination values indicated for the presence of the listed microorganisms exceeds $\mathrm{M}$ or if more than two of the five contaminant values indicated fall between $\mathrm{m}$ and $\mathrm{M}$ [35].

In the studies carried out, it was found that freezing the beaver meat slowed down the growth of the microorganisms studied. The microbiological state of meat stored frozen for 11 weeks was comparable to the state found in meat stored refrigerated for seven days regarding the number of microorganisms. However, our research showed an increase in the number of microorganisms in all bacteria studied in the frozen meat compared to the number of microorganisms found $24 \mathrm{~h}$ after shooting. The multiplication of microorganisms can explain the microbial growth in frozen meat during the thawing process. According to Leygonie et al., during thawing, microorganisms intensively grow due to very favourable growth conditions, especially thanks to the presence of readily available nutrients from thawed meat. In addition, since thawing is a slower process than freezing, some parts of meat may be exposed to more favourable conditions for microbial growth than others [44]. The moisture lost during thawing is rich in proteins, vitamins and minerals derived from the structural disarray caused by the freezing process, which consequently provides an excellent medium for microbial growth [45].

The findings of this study have to take into consideration some limitations. Firstly, there are no current EU food law governing requirements for meat cuts. Therefore, in order to assess the microbiological status of beaver meat cuts, we had to use other available literature sources, such as studies concerning various species of game and food-producing animals. Carcasses of game animals, including beavers, are available only at a certain time of each year and in a certain, small amount. The material collected for research, therefore, has a limited sampling scale.

\section{2. $p H$ and Water Activity}

The results of $\mathrm{pH}$ values obtained in the present research are higher than those reported by Klupsaite et al. for beaver Gluteus medius $24 \mathrm{~h}$ post-mortem (5.61) but lower than values reported previously by Florek et al. for Semimembranosus after 7 days' storage $(6.10)$ [5,9]. Allen et. al., reported in poultry breast very low or not significant correlations between $\mathrm{pH}$ and bacterial counts $[46,47]$. Similarly, Byun et al., found only medium correlations between $\mathrm{pH}$ and bacterial counts during the storage of fresh pork and beef [48]. In turn, in accordance with the opinion of Bruckner et al., meat $\mathrm{pH}$ as an intrinsic factor can be disregarded as an influence on the shelf life of fresh pork and poultry [49].

To the best of our knowledge, no study has previously determined the water activity in beaver meat. Reid et al., observed a decrease in aw from 0.96 to 0.93 in vacuum-packed beef primal cuts during chilled commercial storage for two weeks. In turn, values of $\mathrm{a}_{\mathrm{W}}$ noted in the present study were comparable to the range (between 0.990 and 0.992) reported by Bruckner et al., for fresh poultry and pork stored at $4{ }^{\circ} \mathrm{C}$ for approximately 14 days. However, no significant influence of the $\mathrm{a}_{\mathrm{W}}$ on the shelf life of pork or poultry was found $[49,50]$. 


\section{Conclusions}

The studies proved that the microbiological quality of beaver meat with respect to all the bacteria studied was satisfactory $24 \mathrm{~h}$ after shooting as well as up to the 7 th day of refrigeration storage and up to 11 weeks of freezing. During the above-mentioned time periods, the minced beaver meat met the hygienic (TVC and EC) and food safety criteria (absence of Salmonella) established in Regulation 2073/2006, and it should be processed and consumed.

The high counts of microorganisms found $24 \mathrm{~h}$ after shooting may be related to the prevailing hygienic conditions during the evisceration, skinning and preparation of the carcases of hunted beavers. During the proceedings of the hunted beavers, hunters should make efforts to provide the best hygienic conditions during the handling of beavers' carcases as soon as possible after the animal has been shot.

Pathogenic bacteria such as Listeria and Salmonella were not found in the beaver meat tested. Due to the non-detection of these bacteria, beaver meat can be assessed as safe in terms of the presence of these pathogens.

Based on a significant number of staphylococci in beaver meat, it can be concluded that it will be worth carrying out a thorough species analysis of bacteria of the Staphylococcus genus in beaver meat in the future.

Author Contributions: Conceptualisation, M.F. and M.Z.; methodology, Ł.D., R.P.-Ł., P.D.; software, Ł.D., P.S.; validation, M.G., and F.P.; formal analysis, M.Z., M.G., F.P.; investigation, Ł.D., P.D., M.Z.; resources, M.Z., Ł.D.; data curation, Ł.D.; writing—original draft preparation, M.Z., Ł.D., M.F.; writing - review and editing, R.P.-Ł.; visualisation, P.S.; supervision, M.Z. All authors have read and agreed to the published version of the manuscript.

Funding: The research was financed by the University of Life Sciences in Lublin, grant number WKH-DS-1.

Institutional Review Board Statement: Not applicable.

Informed Consent Statement: Not applicable.

Data Availability Statement: The data used to support the findings of this study are available from the corresponding author upon request.

Conflicts of Interest: The authors declare no conflict of interest.

\section{References}

1. Polish Minister of the Environment. Regulation of the Minister of the Environment of 16 Dec 2016 on the Protection of Animal Species. Official Journal, Item 2183. 2016. Available online: http://isap.sejm.gov.pl/DetailsServlet?id=WDU20160002183 (accessed on 28 December 2016).

2. Statistics Poland, Spatial and Environmental Surveys Department. Statistical Analyses. Environment 2020. Warsaw. 2020. Available online: https:/ /stat.gov.pl/obszary-tematyczne/srodowisko-energia/srodowisko/ochrona-srodowiska-2020,1,21.html (accessed on 30 November 2020).

3. Belova, O. General aspects of beaver hunting and trapping. In Beaver as a renewable resource. In A Beaver Dam handbook for the Baltic Sea Region; Sjöberg, G., Belova, O., Eds.; Swedish Forest Agency: Linköping, Sweden, 2020; pp. 52-61.

4. Domaradzki, P.; Florek, M.; Skałecki, P.; Litwińczuk, A.; Kędzierska-Matysek, M.; Wolanciuk, A.; Tajchman, K. Fatty acid composition, cholesterol content and lipid oxidation indices of intramuscular fat from skeletal muscles of beaver (Castor fiber L.). Meat Sci. 2019, 150, 131-140. [CrossRef] [PubMed]

5. Florek, M.; Drozd, L.; Skałecki, P.; Domaradzki, P.; Litwińczuk, A.; Tajchman, K. Proximate composition and physicochemical properties of European beaver (Castor fiber L.) meat. Meat Sci. 2017, 123, 8-12. [CrossRef]

6. Florek, M.; Skałecki, P.; Domaradzki, P.; Wolan, Ł.; Ryszkowska-Siwko, M. Nutritional value and physicochemical properties of red deer and wild boar meat after frozen storage under vacuum. J. Cent. Eur. Agric. 2017, 18, 278-290. [CrossRef]

7. Razmaitè, V.; Šveistienè, R.; Švirmickas, G.J. Compositional characteristics and nutritional quality of Eurasian beaver (Castor fiber) meat. Czech J. Food Sci. 2011, 29, 480-486. [CrossRef]

8. Florek, M.; Domaradzki, P.; Drozd, L.; Skałecki, P.; Tajchman, K. Chemical composition, amino acid and fatty acid contents, and mineral concentration of European beaver (Castor fiber L.) meat. J. Food Measur. Charact. 2017, 1035-1044. [CrossRef] 
9. Klupsaite, D.; Buckiuniene, V.; Sidlauskiene, S.; Lele, V.; Sakiene, V.; Zavistanaviciute, P.; Klementaviciute, J.; Viskontaite, E.; Bartkiene, E. Comparison studies of the chemical, physical, technological, and microbiological characteristics of the European roe deer, boar, red deer, and beaver hunted wild game meat. Anim. Sci. J. 2020, 91, e13346. [CrossRef]

10. Cliver, D.O.; Riemann, H.P. Foodborne Diseases; Academic Press: London, UK, 2002.

11. Barlow, A.M.; Gottstein, B.; Mueller, N. Echinococcus multilocularis in an imported captive European beaver (Castor fiber) in Great Britain. Vet. Rec. 2011, 169, 339. [CrossRef]

12. Demiaszkiewicz, A.W.; Lachowicz, J.; Kuligowska, I.; Pyziel, A.M.; Bełżecki, G.; Miltko, R.; Kowalik, B.; Gogola, W.; Giżejewski, Z. Endoparasites of the European beaver (Castor fiber L. 1758) in north-eastern Poland. Bull Vet. Inst. Pulawy 2014, 58, $223-227$. [CrossRef]

13. Bronstein, A.M.; Lukashev, A.N. Possible case of trichinellosis associated with beaver (Castor fiber) meat. J. Helminthol. 2019, 93, 372-374. [CrossRef] [PubMed]

14. Różycki, M.; Bilska-Zając, E.; Kochanowski, M.; Grądziel-Krukowska, K.; Zdybel, J.; Karamon, J.; Wiśniewski, J.; Cencek, T. First case of Trichinella spiralis infection in beavers (Castor fiber) in Poland and Europe. Int. J. Parasitol. Parasites Wildl. 2020, 11, 46-49. [CrossRef]

15. Seglina, Z.; Bakasejevs, E.; Deksne, G.; Spunǵis, V.; Kurjušina, M. New finding of Trichinella britovi in a European beaver (Castor fiber) in Latvia. Parasitol. Res. 2015, 114, 3171-3173. [CrossRef] [PubMed]

16. Atanassova, V.; Apelt, J.; Reich, F.; Klein, G. Microbiological quality of freshly shot game in Germany. Meat Sci. 2008, 78, 414-419. [CrossRef] [PubMed]

17. Borilova, G.; Hulankova, R.; Svobodova, I.; Jezek, F.; Hutarova, Z.; Vecerek, V.; Steinhauserova, I. The effect of storage conditions on the hygiene and sensory status of wild boar meat. Meat Sci. 2016, 118, 71-77. [CrossRef] [PubMed]

18. Mirceta, J.; Petrovic, J.; Malesevic, M.; Blagojevic, B.; Antic, D. Assessment of microbial carcass contamination of hunted wild boars. Eur. J. Wildl. Res. 2017, 63, 37. [CrossRef]

19. Casoli, C.; Duranti, E.; Cambiotti, F.; Avellini, P. Wild ungulate slaughtering and meat inspection. Vet. Res. Commun. 2005, 29, 89-95. [CrossRef]

20. European Food Safety Authority (EFSA). Scientific opinion on the public health risks related to the maintenance of the cold chain during storage and transport of meat. Part 1 (meat of domestic ungulates). EFSA J. 2014, 12, 3601. [CrossRef]

21. European Food Safety Authority (EFSA). Scientific opinion on the public health risks related to the maintenance of the cold chain during storage and transport of meat. Part 2 (minced meat from all species). EFSA J. 2014, 12, 3783. [CrossRef]

22. European Council. Regulation (EC). No 853/2004 of the European Parliament and of the Council of 29 Apr 2004 laying down specific hygiene rules for food of animal origin. Off. J. Eur. Union 2004, L 139/55.

23. PN-ISO 6887-2:2005. Microbiology of Food and Animal Feeding Stuffs_Preparation of Test Samples and Decimal Dilutions for Microbiological Examination-Part 2: Specific Rules for the Preparation of Meat and Meat Products; Polish Committee for Standardization: Warsaw, Poland, 2005.

24. PN-ISO 7218:2008. Microbiology of Food and Animal Feeding Stuffs_General Requirements and Guidance for Microbiological Examination; Polish Committee for Standardization: Warsaw, Poland, 2008.

25. Burbianka, M.; Pliszka, A.; Burzyńska, H. Mikrobiologia Żywności; Food Microbiology; Państwowy Zakład Wydawnictw Lekarskich: Warsaw, Poland, 1983.

26. PN-ISO 4833-2:2013-12. Microbiology of the Food Chain-Horizontal Method for the Enumeration of Microorganisms-Part 2: ColonyCount at 30 Degrees C by the Surface Plating Technique; Polish Committee for Standardization: Warsaw, Poland, 2013.

27. PN-ISO 21528-2:2005. Microbiology of Food and Animal Feeding Stuffs-Horizontal Method for the Detection and Enumeration of Enterobacteriaceae - Part 2: Colony-Count Method; Polish Committee for Standardization: Warsaw, Poland, 2005.

28. PN-ISO 16649-2:2004. Microbiology of Food and Animal Feeding Stuffs_Horizontal Method for the Enumeration of $\beta$-GlucuronidasePositive Escherichia coli-Part 2: Colony-Count Technique at $44{ }^{\circ} \mathrm{C}$ Using 5-bromo-4-chloro-3-indolyl $\beta$-D-glucuronide; Polish Committee for Standardization: Warsaw, Poland, 2004.

29. PN-ISO 15214:2002. Microbiology of Food and Animal Feeding Stuffs_-Horizontal Method for the Enumeration of Mesophilic Lactic Acid Bacteria-Colony-Count Technique at $30^{\circ} \mathrm{C}$; Polish Committee for Standardization: Warsaw, Poland, 2002.

30. PN-ISO 6888-1:2001. Microbiology of Food and Animal Feeding Stuffs—Horizontal Method for the Enumeration of Coagulase-Positive Staphylococci Staphylococcus Aureus and Other Species)_Part 1: Technique Using Baird-Parker Agar Medium; Polish Committee for Standardization: Warsaw, Poland, 2001.

31. PN-ISO 21527-1:2009. Microbiology of Food and Animal Feeding Stuffs-Horizontal Method for the Enumeration of Yeasts and MouldsPart 1: Colony-Count Technique in Products with Wather Activity Greater Than 0.95; Polish Committee for Standardization: Warsaw, Poland, 2009.

32. PN-ISO 6579:2003. Microbiology of Food and Animal Feeding Stuffs—Horizontal Method for the Detection of Salmonella spp.; Polish Committee for Standardization: Warsaw, Poland, 2003.

33. PN-ISO 11290-1:1999. Microbiology of Food and Animal Feeding Stuffs—Horizontal Method for the Detection and Enumeration of Listeria Monocytogenes_Part 1: Detection Method; Polish Committee for Standardization: Warsaw, Poland, 1999.

34. Gill, C.O. Microbiological conditions of meats from large game animals and birds. Meat Sci. 2007, 77, 149-160. [CrossRef]

35. European Commission. Commission Regulation (EC) No 2073/2005 of 15 Nov 2005 on microbiological criteria for foodstuffs. Off. J. Eur. Union. 2005, L 338/1. 
36. Daszkiewicz, T.; Kondratowicz, J.; Koba-Kowalczyk, M. Changes in the quality of meat from roe deer (Capreolus L.) bucks during cold storage under vacuum and modified atmosphere. Pol. J. Vet. Sci. 2011, 14, 459-466. [CrossRef]

37. Borilova, G.; Hulankova, R.; Svobodova, I.; Jezek, F.; Hutarova, Z.; Tesarova, S.; Vecerek, V.; Steinhauserova, I. Sensory and microbiological parameters of stored wild boar meat. Procedia Food Sci. 2015, 5, 10-13. [CrossRef]

38. Stella, S.; Tirloni, E.; Castelli, E.; Colombo, F.; Bernardi, C. Microbiological Evaluation of Carcasses of Wild Boar Hunted in a Hill Area of Northern Italy. J. Food Prot. 2018, 81, 1519-1525. [CrossRef]

39. Peruzy, M.F.; Murru, N.; Yu, Z.; Kerkhof, P.J.; Neola, B.; Joossens, M.; Proroga, Y.T.R.; Houf, K. Assessment of microbial communities on freshly killed wild boar meat by MALDI-TOF MS and 16S rRNA amplicon sequencing. Int. J. Food Microbiol. 2019, 301, 51-60. [CrossRef]

40. Ludwiczak, A.; Kulig, D.; Składanowska-Baryza, J.; Bykowska-Maciejewska, M.; Tarnawski, T.; Stanisz, M. The effect of chilled storage on the quality of meat from the feral wild boar (Sus scrofa). Ital. J. Anim. Sci. 2019, 18, 1294-1301. [CrossRef]

41. Liepina, S.; Jemeljanovs, A.; Konošonoka, I.H. Detection of bacterial pollution of roe deer's (Capreolus capreolus) and red deer's (Cervus elaphus) meat using classical microbiological and molecular biology methods. In Proceedings of the International Scientific Conference: Animals, Health, Food Hygiene, Jelgava, Latvia, 29 October 2010; pp. 78-81.

42. Kalschne, D.L.; Womer, R.; Mattana, A.; Pereira Sarmento, C.M.; Colla, L.M.; Colla, E. Characterisation of the spoilage lactic acid bacteria in "sliced vaccum-paced cooked ham". Braz. J. Microbiol. 2015, 46, 173-181. [CrossRef] [PubMed]

43. Lawson, P.A.; Foster, G.; Falsen, E.; Markopoulos, S.J.; Collins, M.D. Streptococcus castoreus sp. nov., isolated from a beaver (Castor fiber). Int. J. Syst. Evol. Microbiol. 2005, 55, 843-846. [CrossRef] [PubMed]

44. Leygonie, C.; Britz, T.J.; Hoffman, L.C. Impact of freezing and thawing on the quality of meat: Review. Meat Sci. 2012, 91, 93-98. [CrossRef] [PubMed]

45. Pham, Q.T. Refrigeration and freezing technology/Thawing. In Encyclopaedia of Meat Science; Jensen, W.K., Ed.; Elsevier Academic Press: Oxford, UK, 2004; Volume 3, pp. 1150-1156.

46. Allen, C.D.; Fletcher, D.L.; Northcutt, J.K.; Russell, S.M. The relationship of broiler breast color to meat quality and shelf-life. Poult. Sci. 1998, 77, 361-366. [CrossRef]

47. Allen, C.D.; Russell, S.M.; Fletcher, D.L. The relationship of broiler breast meat color and $\mathrm{pH}$ to shelf-life and odor development. Poult. Sci. 1997, 76, 1042-1046. [CrossRef] [PubMed]

48. Byun, J.S.; Min, J.S.; Kim, I.S.; Kim, J.W.; Chung, M.S.; Lee, M. Comparison of indicators of microbial quality of meat during aerobic cold storage. J. Food Prot. 2003, 66, 1733-1737. [CrossRef] [PubMed]

49. Bruckner, S.; Albrecht, A.; Petersen, B.; Kreyenschmidt, J. Characterization and comparison of spoilage processes in fresh pork and poultry. J. Food Qual. 2012, 35, 372-382. [CrossRef]

50. Reid, R.; Fanning, S.; Whyte, P.; Kerry, J.; Lindqvist, R.; Yu, Z.; Bolton, D. The microbiology of beef carcasses and primals during chilling and commercial storage. Food Microbiol. 2017, 61, 50-57. [CrossRef] [PubMed] 